\title{
Complex formation during dissolution of metal oxides in molten alkali carbonates
}

\section{Li, Qingfeng; Borup, Flemming; Petrushina, Irina; Bjerrum, Niels}

Published in:

Journal of The Electrochemical Society

Link to article, DOI:

$10.1149 / 1.1391954$

Publication date:

1999

Document Version

Publisher's PDF, also known as Version of record

Link back to DTU Orbit

Citation (APA):

$\mathrm{Li}, \mathrm{Q}$., Borup, $\dot{\mathrm{F}}$., Petrushina, I., \& Bjerrum, N. (1999). Complex formation during dissolution of metal oxides in molten alkali carbonates. Journal of The Electrochemical Society, 146(7), 2449-2454.

https://doi.org/10.1149/1.1391954

\section{General rights}

Copyright and moral rights for the publications made accessible in the public portal are retained by the authors and/or other copyright owners and it is a condition of accessing publications that users recognise and abide by the legal requirements associated with these rights.

- Users may download and print one copy of any publication from the public portal for the purpose of private study or research.

- You may not further distribute the material or use it for any profit-making activity or commercial gain

- You may freely distribute the URL identifying the publication in the public portal

If you believe that this document breaches copyright please contact us providing details, and we will remove access to the work immediately and investigate your claim. 


\title{
Complex Formation during Dissolution of Metal Oxides in Molten Alkali Carbonates
}

\author{
Li Qingfeng,* Flemming Borup, Irina Petrushina,* and Niels J. Bjerrum*
}

\author{
Materials Science Group, Department of Chemistry, Technical University of Denmark, 2800 Lyngby, Denmark
}

\begin{abstract}
Dissolution of metal oxides in molten carbonates relates directly to the stability of materials for electrodes and construction of molten carbonate fuel cells. In the present work the solubilities of $\mathrm{PbO}, \mathrm{NiO}, \mathrm{Fe}_{2} \mathrm{O}_{3}$, and $\mathrm{Bi}_{2} \mathrm{O}_{3}$ in molten $\mathrm{Li} / \mathrm{K}$ carbonates have been measured at $650^{\circ} \mathrm{C}$ under carbon dioxide atmosphere. It is found that the solubilities of $\mathrm{NiO}$ and $\mathrm{PbO}$ decrease while those of $\mathrm{Fe}_{2} \mathrm{O}_{3}$ and $\mathrm{Bi}_{2} \mathrm{O}_{3}$ remain approximately constant as the lithium mole fraction increases from 0.43 to 0.62 in the melt. At a fixed composition of the melt, $\mathrm{NiO}$ and $\mathrm{PbO}$ display both acidic and basic dissolution as the partial pressure of carbon dioxide varies. By combination of solubility and electromotive force measurements, a model is constructed assuming the dissolution involves complex formation. The possible species for lead are proposed to be $\left[\mathrm{Pb}\left(\mathrm{CO}_{3}\right)_{2}\right]^{-2}$ and/or $\left[\mathrm{Pb}\left(\mathrm{CO}_{3}\right)_{3}\right]^{-4}$. A similar complex chemistry for nickel oxide dissolution might be expected.
\end{abstract}

(C) 1999 The Electrochemical Society. S0013-4651(98)11-017-0. All rights reserved.

Manuscript submitted November 2, 1998; revised manuscript received February 1, 1999.

Dissolution of metal oxides in molten carbonates is of importance because of its relationship to the stability of the electrode and construction materials for molten carbonate fuel cells (MCFC).

The earlier investigations on MCFC, up to 1970 s, were concentrated on silver for both anode and cathode. It was shown, however, that silver was unsuitable for long-term use due to its high solubility in the carbonate melt under cathode-side conditions. ${ }^{1,2}$

$\mathrm{NiO}$, in the lithiated form for high conductivity, still seems to be the most promising material for the MCFC cathode. It is, however, unlikely to attain a lifetime more than $40,000 \mathrm{~h}$ because of its solubility in the carbonate melt. Several investigations have been carried out to measure the solubility of $\mathrm{NiO}$ in individual alkali carbonates, ${ }^{3}$ binary mixtures, ${ }^{4-7}$ ternary mixtures, ${ }^{8,9}$ and alkali/alkaline earth carbonate mixtures. ${ }^{10,11}$

In order to obtain other materials as possible substitutes for the lithiated $\mathrm{NiO}$ cathode, extensive research has been conducted. Among the numerous candidates of pervoskite-type compounds and mixed metal oxides, the chemistry of $\mathrm{CuO},{ }^{12,13} \mathrm{ZnO},{ }^{12,13}$ $\mathrm{LiFeO}_{2},{ }^{12-15} \quad(\mathrm{Li}, \mathrm{K})_{2} \mathrm{CrO}_{4},{ }^{15} \quad \mathrm{LaNiO}_{3},{ }^{12,13} \quad \mathrm{Li}_{2} \mathrm{MnO}_{3},{ }^{13,17}$ $\mathrm{LiCoO}_{2},{ }^{16-19}$ and $\mathrm{La}_{2} \mathrm{ZrO}_{3}{ }^{20}$ has been investigated in the alkali carbonate mixtures in the temperature range between 550 and $950^{\circ} \mathrm{C}$.

The dissolution of metal oxides in molten alkali carbonates is believed to be controlled by the acid/base chemistry of the solvent. The acid/base concept, postulated for the oxyanion-containing molten salt systems by Lux ${ }^{21}$ and Flood and Forland, ${ }^{22}$ is analogous to the Brøndsted concept for aqueous solutions. The oxide ion, $\mathrm{O}^{2-}$, is considered to be the basic component of the solvent in the same sense that the hydrogen ion defines acidity in aqueous solutions. Alkali metal carbonates dissociate according to the following equilibrium

$$
\begin{gathered}
\mathrm{M}_{2} \mathrm{CO}_{3(\mathrm{l})} \rightleftarrows 2 \mathrm{M}^{+}+\mathrm{CO}_{3}^{2-} \\
\mathrm{CO}_{3}^{2-} \rightleftarrows \mathrm{O}^{2-}+\mathrm{CO}_{2(\mathrm{~g})}
\end{gathered}
$$

where $\mathrm{CO}_{3}^{2-}$ is identified as the basic component and the gaseous $\mathrm{CO}_{2}$ (which is presumed to be in equilibrium with that in the melt) as the acidic component. The basicity/acidity of the melt can therefore be defined by a function of either $-\log a_{\mathrm{O}^{2}}-$ or $-\log p_{\mathrm{CO}_{2}}$.

Transition metal oxides, e.g., nickel oxide $\mathrm{NiO}$, are found to dissolve in the carbonate melt either in an acidic mode or in a basic mode. When the oxide ion activity in the melt is very low, corresponding to a high partial pressure of $\mathrm{CO}_{2}$, the acidic dissolution is supposed to occur

$$
\mathrm{NiO} \rightleftarrows \mathrm{Ni}^{2+}+\mathrm{O}^{2-}
$$

or

\footnotetext{
* Electrochemical Society Active Member.
}

$$
\mathrm{NiO}+\mathrm{CO}_{2} \rightleftarrows \mathrm{Ni}^{2+}+\mathrm{CO}_{3}^{2-}
$$

At a high oxide ion activity or a low partial pressure of $\mathrm{CO}_{2}$, the basic dissolution occurs by reacting with oxide ions to form complex anions such as $\mathrm{NiO}_{2}^{2-}$

$$
\mathrm{NiO}+\mathrm{O}^{2-} \rightleftarrows \mathrm{NiO}_{2}^{2-}
$$

or

$$
\mathrm{NiO}+\mathrm{CO}_{3}^{2-} \rightleftarrows \mathrm{NiO}_{2}^{2-}+\mathrm{CO}_{2}
$$

$\mathrm{NiO}^{-}$or $\mathrm{NiO}_{3}^{2-}$, as suggested by Orfield and Shores, ${ }^{3}$ may also be the products of the basic dissolution, where the formal oxidation states are +3 and +4 , respectively. The mechanism of basic dissolution has not been elucidated since little is known about the stability of various nickelate ions. It is however the acidic dissolution that governs the process under the cathodic conditions of an MCFC.

If the activity coefficient of the dissolved nickel species is assumed to be constant, a plot of the logarithm of the NiO solubility as a function of the melt basicity, e.g., $-\log p_{\mathrm{CO}_{2}}$, would show two distinct regimes of dissolution. According to reaction 3, the acid dissolution will be represented as a straight line with a slope of +1 .

For single molten carbonates of alkali metals, it is reported that the solubility in both acidic and basic regimes increases in an order from $\mathrm{Li}_{2} \mathrm{CO}_{3}$ to $\mathrm{Rb}_{2} \mathrm{CO}_{3}{ }^{3}$ The slopes of the basic dissolution lines decrease from -1.0 for $\mathrm{Li}_{2} \mathrm{CO}_{3}$ and $\mathrm{Na}_{2} \mathrm{CO}_{3}$ to -0.5 for $\mathrm{Rb}_{2} \mathrm{CO}_{3}$. A corresponding trend in the slopes of the acidic solubility also exists but does not appear to follow the chemistry of the solvent. The values of the slopes are found to be +1.0 for $\mathrm{Na}_{2} \mathrm{CO}_{3},+1.4$ for $\mathrm{K}_{2} \mathrm{CO}_{3}$, and +1.2 for $\mathrm{Rb}_{2} \mathrm{CO}_{3}$. For $\mathrm{Li}_{2} \mathrm{CO}_{3}$, however, no acidic dissolution is observed.

In a mixture of two or more alkali carbonates, the melt basicity is a function of both the $p_{\mathrm{CO}_{2}}$ above the melt and the mole fraction of the alkali cations. In a binary mixture of $\mathrm{Li}_{2} \mathrm{CO}_{3}$ and $\mathrm{K}_{2} \mathrm{CO}_{3}$, for example, the basicity is a function directly proportional $p_{\mathrm{CO}_{2}}$ when the composition is fixed. If the partial pressure of $\mathrm{CO}_{2}$ is fixed, the basicity is, however, a nonlinear function of the mole fractions of the melt components. ${ }^{6}$

In binary mixtures of $\mathrm{Li}-\mathrm{K}, \mathrm{Li}-\mathrm{Na}$, and $\mathrm{Na}-\mathrm{K}$ carbonates, both acidic and basic dissolution of $\mathrm{NiO}$ has been observed. Orfield and Shores ${ }^{6}$ reported that the $\mathrm{Li}_{2} \mathrm{CO}_{3}$-rich mixtures (higher than $50 \%$ mol $\mathrm{Li}_{2} \mathrm{CO}_{3}$ at $910^{\circ} \mathrm{C}$ ) showed only the basic dissolution, while the results from Ota et al. ${ }^{7}$ and Doyon et al. ${ }^{10}$ for the $\mathrm{Li} / \mathrm{K}=62 / 38$ melt showed a well-defined acidic dissolution in the temperature range from 650 to $750^{\circ} \mathrm{C}$. The temperature difference may partly account for this by considering the fact that the free energy of dissociation of an alkali carbonate depends upon the temperature of the melt and the dissolution of metal oxides depends on the basicity. 
The assumption of a simple acidic dissolution (reaction 3 ) seems to be valid, since Doyon et al. ${ }^{10}$ and Ota et al. ${ }^{7}$ obtained slopes of acidic dissolution lines around +1 . Furthermore Doyon et al. ${ }^{10}$ and Plomp et al. ${ }^{11}$ demonstrated that the addition of basic oxides $(\mathrm{MgO}$ and $\mathrm{SrO}$ ) into the $\mathrm{Li} / \mathrm{K}=62 / 38$ melt led to a decrease in solubility of $\mathrm{NiO}$. At different compositions of the $\mathrm{Li} / \mathrm{K}$ binary carbonates, the $\mathrm{NiO}$ solubility was found to decrease with an increase in the content of lithium salt. The similarity of the lithium effect to that of $\mathrm{MgO}$ and $\mathrm{SrO}$ led some workers ${ }^{6,7,10}$ to conclude that $\mathrm{Li}_{2} \mathrm{CO}_{3}$ is the most basic salt among the three alkali carbonates (basic $\mathrm{Li}_{2} \mathrm{CO}_{3}>$ $\mathrm{Na}_{2} \mathrm{CO}_{3}>\mathrm{K}_{2} \mathrm{CO}_{3}$ acidic).

On the other hand, in addition to the variant slopes for single carbonates, ${ }^{3}$ Orfield and Shores ${ }^{6}$ reported acidic dissolution slopes between 0.65 and 0.80 for all compositions of $\mathrm{Na}_{2} \mathrm{CO}_{3}-\mathrm{K}_{2} \mathrm{CO}_{3}$ and $\mathrm{Li}_{2} \mathrm{CO}_{3}-\mathrm{K}_{2} \mathrm{CO}_{3}$ with an exception of the $0.96 \mathrm{~K}_{2} \mathrm{CO}_{3}-0.04 \mathrm{Li}_{2} \mathrm{CO}_{3}$ melt, where the slope was found to be close to 1 .

Orfield and Shores ${ }^{6}$ suggested that the variant slopes of the acidic dissolution lines may best be correlated with the difference between the temperature of experiments and the melting point of the melts. When the temperature difference is larger than $100^{\circ} \mathrm{C}$, the slope was found to be constant for all mixtures regardless of components or compositions, but being around 0.7 instead of the expected 1.0. They calculated the basicity of the melt for different temperatures and replotted the solubility data as a function of this calculated basicity [at a constant $p_{\mathrm{CO}_{2}}$ ]. They obtained, however, slopes of less than 0.2 , being very different from those of the solubility vs. basicity lines at a constant temperature but different $p_{\mathrm{CO}_{2}}$.

Moreover, when Orfield and Shores ${ }^{6}$ replotted the solubility data of $\mathrm{NiO}$ at different $\mathrm{Li}_{2} \mathrm{CO}_{3}$ contents as a function of the calculated basicity (at a fixed $\mathrm{CO}_{2}$ pressure), they found that, although the basicity varies over four orders of magnitude with an addition of $10 \% \mathrm{Li}_{2} \mathrm{CO}_{3}$ to $\mathrm{K}_{2} \mathrm{CO}_{3}$, the solubility remains almost identical to that of pure $\mathrm{K}_{2} \mathrm{CO}_{3}$. With larger additions of $\mathrm{Li}_{2} \mathrm{CO}_{3}$, as the composition approaches pure $\mathrm{Li}_{2} \mathrm{CO}_{3}$, the basicity changes by only one order of magnitude, but the solubility of $\mathrm{NiO}$ decreases considerably.

The above arguments evidently obscure the simple mechanism of the acid/base dissolution of metal oxides in alkali carbonates. As Orfield and Shores ${ }^{3,6}$ proposed, the formation of complex ions might be one of the explanations. This paper is devoted to an investigation of the solubility of metal oxides from the viewpoint of the complex formation.

\section{Experimental}

The solubilities of $\mathrm{PbO}, \mathrm{NiO}, \mathrm{Bi}_{2} \mathrm{O}_{3}$, and $\mathrm{Fe}_{2} \mathrm{O}_{3}$ were measured in $\left(\mathrm{Li}_{x} \mathrm{~K}_{1-x}\right)_{2} \mathrm{CO}_{3}$ melts with $x$ between 0.43 and 0.62 . The alkali carbonates, $\mathrm{Li}_{2} \mathrm{CO}_{3}$ (Riedel-De Haen, analytic) and $\mathrm{K}_{2} \mathrm{CO}_{3}$ (Merck, analytic), were ground at room temperature and mixed for $72 \mathrm{~h}$ before melting at $650^{\circ} \mathrm{C}$. Powders of $\mathrm{PbO}(99.9 \%$ Aldrich) and $\mathrm{Bi}_{2} \mathrm{O}_{3}$ (99.8\% Johnson Matthey) were first melted in air, cooled, and crushed to obtain oxide pellets. The $\mathrm{Fe}_{2} \mathrm{O}_{3}$ and $\mathrm{NiO}$ powders (both $99 \%$ from Aldrich) were sintered as pellets at $800^{\circ} \mathrm{C}$ in air. The metal oxide pellets were then placed in an alumina crucible (id $4 \mathrm{~cm}$ and height $6.5 \mathrm{~cm}$ ) and covered with about $100 \mathrm{~g}$ of the premixed carbonates. The mixture was heated to $650^{\circ} \mathrm{C}$ under an atmosphere of pure $\mathrm{CO}_{2}$. The gas (either pure $\mathrm{CO}_{2}$ or $\mathrm{CO}_{2}$-Ar mixture) was then bubbled through the melt by means of an alumina inlet tube to ensure that the melt was saturated with the gas. Gaseous $\mathrm{CO}_{2}$, argon, and a premade mixture of $0.50( \pm 0.005) \% \mathrm{CO}_{2}$ in Ar were provided by Hede Nielsen A/S, and from these the mixed gas of other compositions was obtained by means of mass-flow meters and a controller (Bronkhorst, HI-TEC E-5514). Initial tests were conducted for each oxide to determine the time needed for reaching the equilibrium at the studied experimental conditions.

The alumina inlet tube was lifted just above the melt for an hour before the sampling took place in order to allow any particles to settle. Melt samples (5 to $6 \mathrm{~g}$ ) were taken by means of a quartz tube from the melt just under the upper surface. The samples containing different oxides were then dissolved in diluted acetic acid. After evaporation, the remains were dissolved in $0.1 \mathrm{M}$ nitric acid and ana- lyzed by atomic absorption spectroscopy (Perkin Elmer 2100). Due to its high solubility, $\mathrm{PbO}$ was analyzed gravimetrically by precipitation as $\mathrm{PbCrO}_{4}$.

An electrochemical cell

$$
\begin{aligned}
& \mathrm{Pb} \mid \mathrm{CO}_{2}, \mathrm{PbO}_{\text {(sat.) }},(\mathrm{Li}-\mathrm{K})_{2} \mathrm{CO}_{3(1)} \|\left(\mathrm{Li}-\mathrm{K}_{2} \mathrm{CO}_{3(2)},\right. \\
& \mathrm{PbO}_{\text {(sat.) }}, \\
& \mathrm{Ar}-\mathrm{CO}_{2} \mid \mathrm{Pb}
\end{aligned}
$$

was constructed for EMF measurements. Here the melt composition in the left side was kept at $x_{\mathrm{Li}}=0.43$, while the melt composition in the right side varied from $x_{\mathrm{Li}}=0.43$ to 0.62 . Both melts were saturated with lead oxide under variant partial pressures of carbon dioxide. Liquid lead was used as electrodes in both chambers with pure iron as the connection wire. The apparatus is shown in Fig.1. The connection between the two half-cells was made by cutting the side wall of both tubes and blocking the resulting holes with porous alumina. The temperature in the melt was measured with a Pt/Pt-10\% $\mathrm{Rh}$ thermocouple protected by an alumina tube.

\section{Results and Discussion}

Solubility measurements.-Figure 2 shows the dissolution curves of $\mathrm{PbO}$ under an atmosphere of pure $\mathrm{CO}_{2}$ at $650^{\circ} \mathrm{C}$ in lithium-potassium melts with lithium mole fractions of $0.43,0.51$, and 0.62 ,

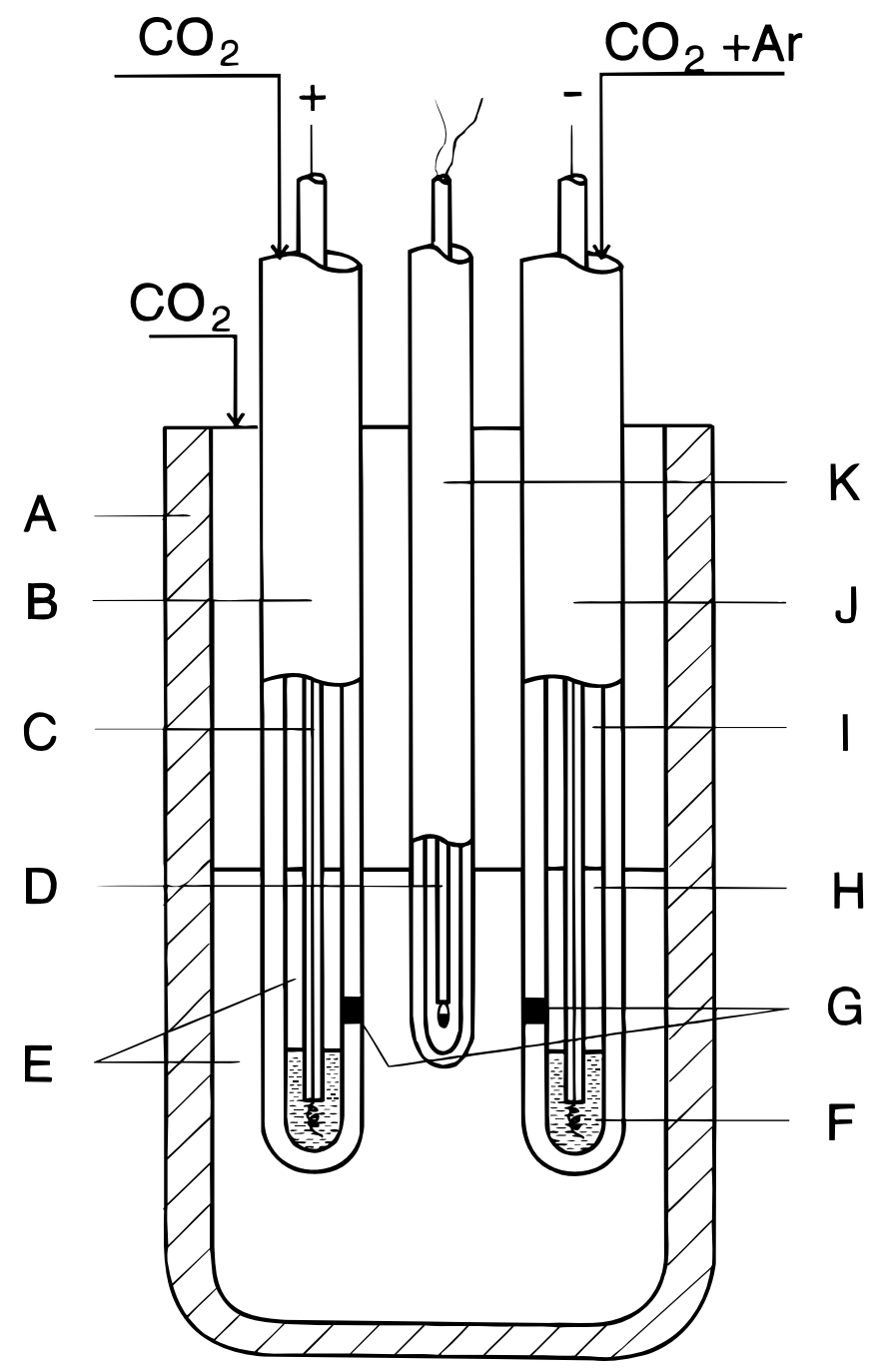

Figure 1. Experimental setup for EMF measurements. A, alumina crucible; $\mathrm{B}$, reference electrode chamber; $\mathrm{C}$, alumina tube covered iron wire; $\mathrm{D}$, thermocouple; E, Li/K (43/57) melt; F liquid lead; G, porous alumina diaphragm; $\mathrm{H}, \mathrm{Li} / \mathrm{K}$ melt of various composition; I, alumina tube covered iron wire; $\mathrm{J}$, measuring electrode chamber; and $\mathrm{K}$, alumina tube for thermocouple. 


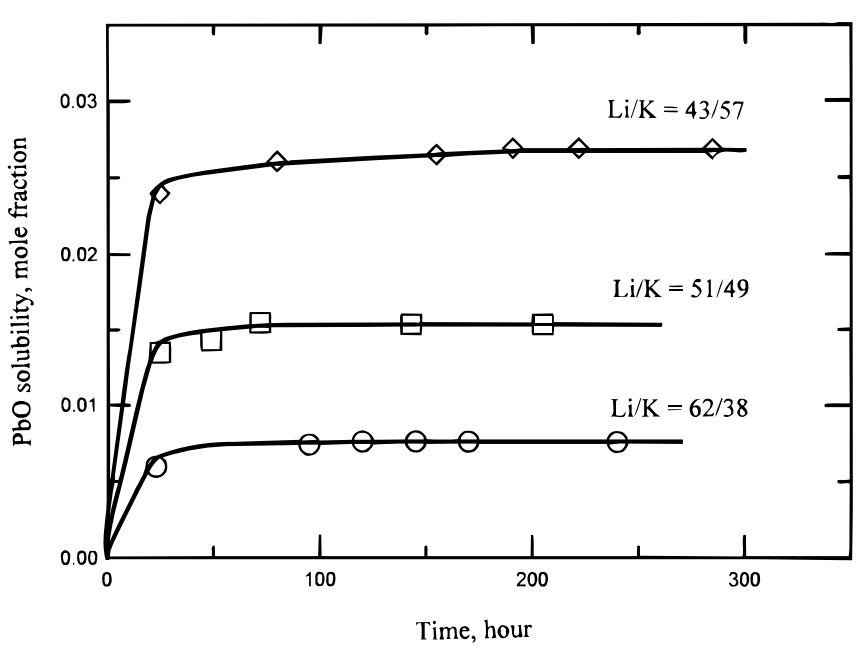

Figure 2. Dissolution curves for lead oxide in $\mathrm{Li} / \mathrm{K}$ carbonate melts at $650^{\circ} \mathrm{C}$ under $1 \mathrm{~atm}$ of carbon dioxide. The melt composition in mole ratio is indicated in the figure.

respectively. The concentrations are presented in mole fractions of the oxide in carbonate melts (the same for other oxide solubility data below). The lead content in the melt increases during the experiment and reaches a steady state after about $100 \mathrm{~h}$. The solubility was then determined from these steady-state values. For other oxides similar measurements were carried out, and the solubilities were determined also after $100 \mathrm{~h}$.

It is clearly seen from Fig. 2 that the solubility of $\mathrm{PbO}$ depends on the melt composition. This dependence is also valid for nickel oxide. Figure 3 summarizes the solubility data of $\mathrm{PbO}, \mathrm{Bi}_{2} \mathrm{O}_{3}, \mathrm{NiO}$, and $\mathrm{Fe}_{2} \mathrm{O}_{3}$ as a function of the mole fraction of lithium carbonate in

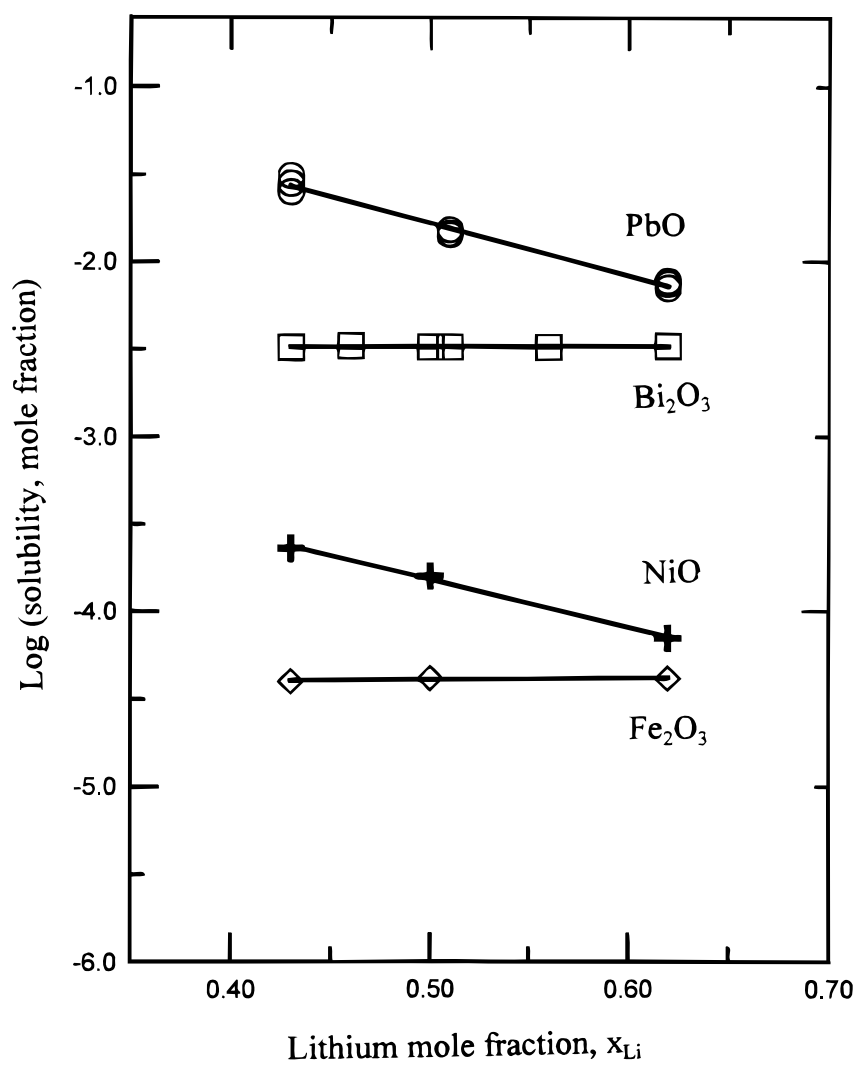

Figure 3. Solubility of metal oxides as a function of lithium mole fraction in $\mathrm{Li} / \mathrm{K}$ carbonates at $650^{\circ} \mathrm{C}$ under $1 \mathrm{~atm}$ of carbon dioxide. the melt at $650^{\circ} \mathrm{C}$ and $1 \mathrm{~atm}$ of carbon dioxide. It can be seen that, although the absolute values of $\mathrm{PbO}$ and $\mathrm{NiO}$ solubilities are hundreds of times different, both compounds show a very similar reduction in solubility as the lithium mole fraction increases. In the range of $x_{\mathrm{Li}}$ from 0.43 to 0.62 , the logarithm of the solubility vs. lithium mole fraction $\left(x_{\mathrm{Li}}\right)$ for both oxides has a slope around -2.8 .

The solubility of $\mathrm{Bi}_{2} \mathrm{O}_{3}$ is also about a hundred times larger than that of $\mathrm{Fe}_{2} \mathrm{O}_{3}$, but the solubility of neither oxide varies as the lithium mole fraction increases from 0.43 to 0.62 . In their measurement in $62 \% \mathrm{Li}_{2} \mathrm{CO}_{3}-38 \% \mathrm{~K}_{2} \mathrm{CO}_{3}$ melts at $650^{\circ} \mathrm{C}$, Hsu et al. ${ }^{15}$ obtained a $\mathrm{LiFeO}_{2}$ solubility value (ca. $81 \mathrm{~mol} \mathrm{ppm}$ ), close to the present work (58 mol ppm ). They also found that the solubility is independent of $p_{\mathrm{CO}_{2}}$ or $p_{\mathrm{O}_{2}}$ in the investigated range, indicating that the dissolution is not of acid-base nature. As seen from Fig. 3, there is no dependence of the $\mathrm{Fe}_{2} \mathrm{O}_{3}$ and $\mathrm{Bi}_{2} \mathrm{O}_{3}$ solubilities on lithium mole fraction. This gives further evidence to a nonacid/nonbase mechanism. If it is a simple acid/base chemistry that governs the dissolution of metal oxides in molten carbonates, as previously believed for $\mathrm{NiO}$, the lithium effect will merely change the activity of the oxide in the melt, and the oxide activity, in turn, affects the dissolution of metal oxides via an acid/base equilibrium. This, however, does not seem to be the case, especially for the $\mathrm{Fe}_{2} \mathrm{O}_{3}$ and $\mathrm{Bi}_{2} \mathrm{O}_{3}$ dissolution.

It is also interesting to notice that the solubility of the two bivalent metal oxides $(\mathrm{NiO}$ and $\mathrm{PbO})$ behaves the same way with respect to the lithium effect, while that of the two trivalent metal oxides $\left(\mathrm{Fe}_{2} \mathrm{O}_{3}\right.$ and $\left.\mathrm{Bi}_{2} \mathrm{O}_{3}\right)$ behaves the other way. This can be either coincidental or indicating a connection, for example, to the oxidation states of the metals. However, no further investigation was carried out in the present work.

Orfield and Shores ${ }^{6}$ have made a measurement of $\mathrm{NiO}$ solubility in melts of different $\mathrm{Li} / \mathrm{K}$ compositions at $910^{\circ} \mathrm{C}$. For the acidic solubility $\left(p_{\mathrm{CO}_{2}}=0.75\right)$ in melts containing lithium carbonate less than $50 \mathrm{~mol} \%$, they obtained a straight line when plotting $\log \left(x_{\mathrm{NiO}}\right)$ against $\log a_{\mathrm{K}_{2} \mathrm{CO}_{3}}$. It is, however, interesting that a straight line is also obtained when the $\log \left(x_{\mathrm{NiO}}\right)$ is plotted against the mole fraction of lithium carbonate in the range from $0.04 \mathrm{~mol} \%$ to $50 \mathrm{~mol} \% \mathrm{Li}_{2} \mathrm{CO}_{3}$.

Ota et al. ${ }^{7}$ made a measurement of $\mathrm{NiO}$ solubility in melts of different $\mathrm{Li} / \mathrm{K}$ compositions under $p_{\mathrm{CO}_{2}}=1$ atm in a temperature range from 600 to $750^{\circ} \mathrm{C}$. One set of their solubility data (from $750^{\circ} \mathrm{C}$ ) is replotted as a function of the $\mathrm{CO}_{2}$ partial pressure, together with the solubility data for $\mathrm{PbO}$ at $650^{\circ} \mathrm{C}$ from the present study (Fig. 4). The dependence of $\mathrm{PbO}$ and $\mathrm{NiO}$ solubility upon the $\mathrm{CO}_{2}$ partial pressure is very much the same, i.e., the solubility decreases with decreasing $p_{\mathrm{CO}_{2}}$ in the high-pressure range but increases with decreasing $p_{\mathrm{CO}_{2}}$ in the low pressure range. The minimum solubility for $\mathrm{NiO}$ and $\mathrm{PbO}$ appears at nearly the same partial pressure of carbon dioxide.

For the acidic dissolution at $p_{\mathrm{CO}_{2}}$ higher than $0.1 \mathrm{~atm}$, the slopes of the $\log \left(x_{\mathrm{NiO}}\right)-\log \left(p_{\mathrm{CO}_{2}}\right)$ are claimed to be around unity by Ota et al. ${ }^{7}$ and Doyon et al. ${ }^{10}$ as well. For PbO from the present work, however, a linear regression of $\log \left(x_{\mathrm{NiO}}\right)$ vs. $\log \left(p_{\mathrm{CO}_{2}}\right)$ gives the acidic slopes between 0.88 and 0.91 for three compositions of the melt. The slopes of the basic solubility lines for $\mathrm{PbO}$, when the $\mathrm{CO}_{2}$ pressure is lower than $0.01 \mathrm{~atm}$, are found to be about -0.3 , similar to that for $\mathrm{NiO}$ solubility reported by Ota et al. ${ }^{7}$ and Doyon et al. ${ }^{10}$

EMF measurements. - The EMF results are shown in Fig. 5. With the melt of $x_{\mathrm{Li}}=0.43$ and $p_{\mathrm{CO}_{2}}=1$ as reference in the left chamber of the cell, the measured EMF values vary with the mole fraction of lithium carbonate in the melt and the $\mathrm{CO}_{2}$ partial pressure of the gas phase of the right chamber. For a lithium mole fraction from 0.43 to 0.51 and 0.62 under $p_{\mathrm{CO}_{2}}=1$, the EMF increases by 22 and $39 \mathrm{mV}$, respectively.

When, however, the partial pressure of carbon dioxide decreases, the measured EMF decreases (see Fig. 6). In the $x_{\mathrm{Li}}=0.51$ melt, for example, a decrease in $p_{\mathrm{CO}_{2}}$ from $1 \mathrm{~atm}$ to 0.25 and $0.1 \mathrm{~atm}$ leads to a decrease of the EMF by 39 and $85 \mathrm{mV}$, i.e., from 22 to $-17 \mathrm{mV}$ and $-63 \mathrm{mV}$, respectively.

For an approximate evaluation of the liquid-junction potential, Andersen $^{23}$ suggested an expression using the ionic mobility instead 


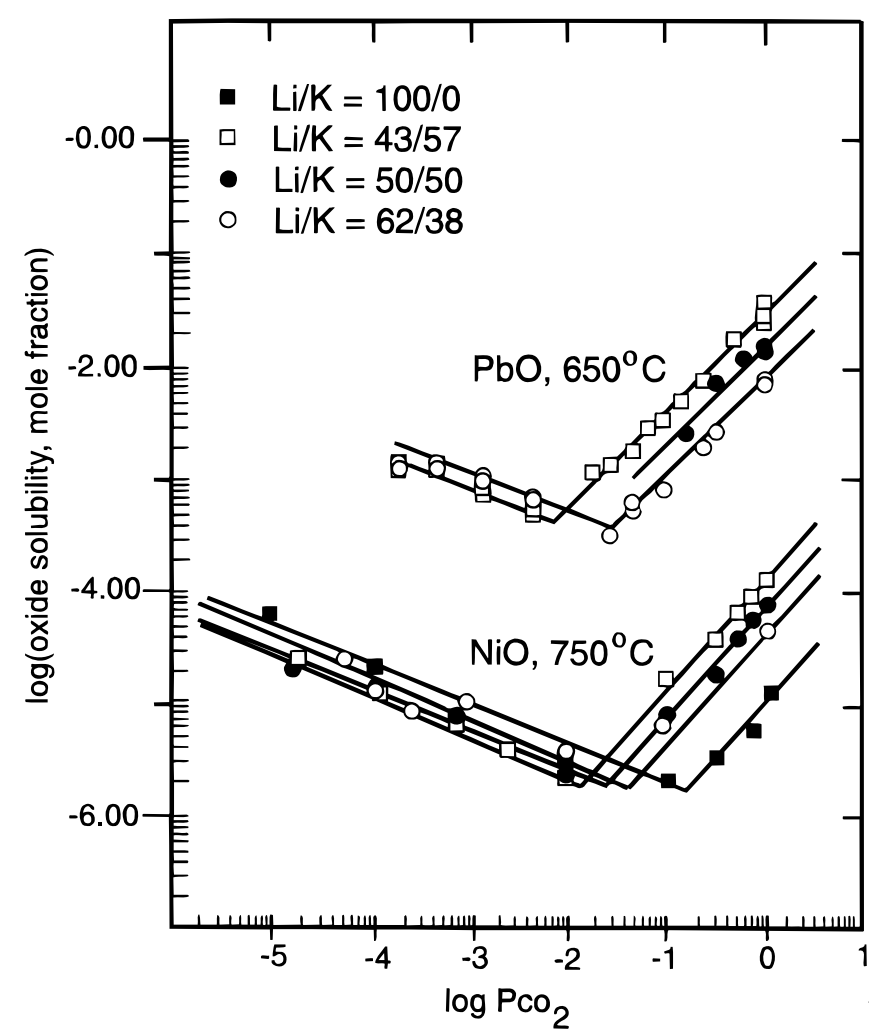

Figure 4. Solubility of metal oxides as a function of carbon dioxide partial pressure in $\mathrm{Li} / \mathrm{K}$ carbonates. $\mathrm{PbO}$ data at $650^{\circ} \mathrm{C}$ from the present work, and $\mathrm{NiO}$ data at $750^{\circ} \mathrm{C}$ from Ota et al. ${ }^{7}$ The melt composition is indicated in the figure.

of the transference number, the former being less sensitive to concentration. Consider the liquid junction potential

$$
\mathrm{Li}_{2} \mathrm{CO}_{3}-\mathrm{K}_{2} \mathrm{CO}_{3(1)} \| \mathrm{Li}_{2} \mathrm{CO}_{3}-\mathrm{K}_{2} \mathrm{CO}_{3(2)}
$$

Assuming that the system mainly consists of $\mathrm{Li}^{+}, \mathrm{K}^{+}$, and $\mathrm{CO}_{3}^{2-}$, and their mobilities are invariable over the studied concentration range, and taking the carbonate anion as the velocity reference $\left[u\left(\mathrm{CO}_{3}^{2-}\right)=0\right)$, one has

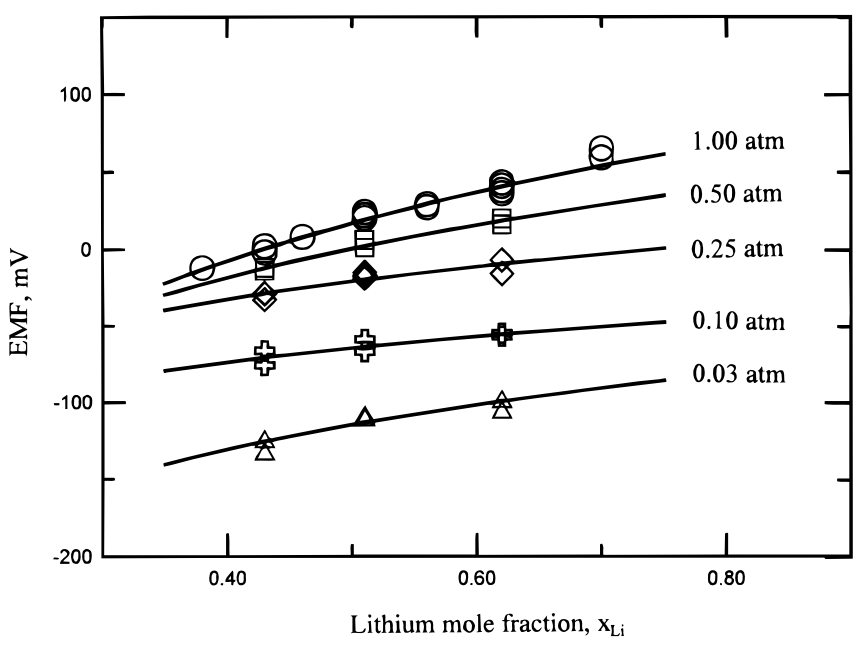

Figure 5. The EMF of the electrochemical cell as a function of lithium mole fraction under various partial pressures of carbon dioxide. The reference electrode: $\mathrm{Li} / \mathrm{K}=0.43$ and $p_{\mathrm{CO}_{2}}=1 \mathrm{~atm}$; temperature: $650^{\circ} \mathrm{C}$. The carbon dioxide partial pressure is indicated in the figure.

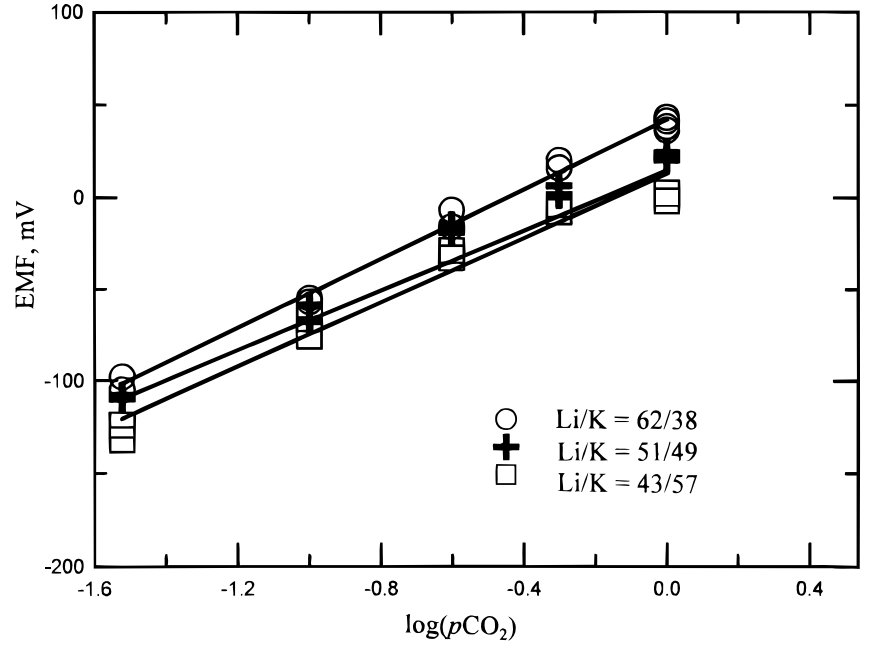

Figure 6. The EMF of the electrochemical cell as a function of carbon dioxide partial pressure. The reference electrode: $\mathrm{Li} / \mathrm{K}=0.43$ and $p_{\mathrm{CO}_{2}}=1 \mathrm{~atm}$; temperature: $650^{\circ} \mathrm{C}$. The melt composition is indicated in the figure.

$$
\Delta \varphi=(R T / n F) \int_{(1)}^{(2)}\left(u_{1} d X_{1}+u_{2} d X_{2}\right) /\left(u_{1} X_{1}+u_{2} X_{2}\right)
$$

where $u_{1}, u_{2}$ are the mobilities, and $X_{1}, X_{2}$ are the mole fractions of $\mathrm{Li}^{+}$and $\mathrm{K}^{+}$, respectively. The mole fraction range studied in the present work is from $x_{\mathrm{Li}}=0.43$ to 0.62 . At $923 \mathrm{~K}$ for $u_{1}=2 u_{2}$, one has $\Delta \varphi<5 \mathrm{mV}$, small compared with the measured EMF values.

Model for complex formation.-As seen from the solubility and EMF measurements, any decrease in carbon dioxide partial pressure results in a decrease in the EMF value and in the solubility of the metal oxide. Keeping the solvent equilibrium (reaction 2) in mind, one expects a higher oxide activity as carbon dioxide partial pressure decreases. This, in turn, corresponds to a more negative value of EMF.

On the other hand, an increase in the lithium mole fraction of the melt leads to a decrease in the solubility of the metal oxide but an increase in the EMF value. This contradiction, compared with the effect of the carbon dioxide partial pressure, may suggest a more complicated mechanism than the previously assumed acid/base chemistry for metal oxide dissolution in molten carbonates. We try to understand the phenomena by applying the assumption of complex formation to the dissolution of metal oxides.

In order to relate the solubility and EMF data to the assumption of complex formation, the following model is suggested by considering the mechanism of the dissolution of a divalent metal oxide

$$
\mathrm{MO}+\mathrm{CO}_{2}+(n-1) \mathrm{CO}_{3}^{2-} \rightleftarrows\left[\mathrm{M}\left(\mathrm{CO}_{3}\right)_{n}\right]^{-2 n+2}
$$

where $\mathrm{M}$ is a divalent metal and $n$ is a number to be determined. With $n=1$, the formula corresponds to the formation of a simple carbonate of lead, while $n>1$ corresponds to the formation of negatively charged complex ions.

Here it is assumed that the metal oxide is not involved in redox reactions as far as the acidic dissolution is concerned, even though this may not be true when the basic dissolution is present. Several measurements ${ }^{6,7,10}$ have shown that the solubility of transition metal oxides (e.g., $\mathrm{NiO}$ ) is independent of the partial pressure of oxygen. Therefore the involvement of gaseous oxygen, being either produced or consumed during the dissolution of metal oxides, is not considered. Furthermore, the formation of any $\mathrm{LiMO}_{x}$ compound from the reaction between metal oxides and $\mathrm{Li}_{2} \mathrm{CO}_{3}$ will only affect the model when the $\mathrm{CO}_{2}$ pressure is varied.

Considering the linear relationship between the metal oxide solubility and carbon dioxide partial pressure in the acidic region, one would expect the formed complex in a monomeric form. In addition 
the coordination number, $n$, should be expected to be of low value so that an unlikely high charge number $(-2 n+2)$ of the complex ion can be avoided.

By further assuming the activity coefficient of the dissolved metal oxide as unity, a relationship between the oxide solubility $\left(x_{\mathrm{Pb}^{2}+}\right)$, carbon dioxide pressure $\left(p_{\mathrm{CO}_{2}}\right)$, and carbonate activity can then be expressed as

$$
K_{\mathrm{p}}=\left(x_{\mathrm{Pb}^{2+}}\right) /\left(p_{\mathrm{CO}_{2}} a_{\mathrm{CO}_{3}^{2-}}{ }^{(n-1)}\right)
$$

With consideration of the solvent equilibrium (reaction 2), with the dissociation constant

$$
K_{\mathrm{d}}=p_{\mathrm{CO}_{2}} a_{\mathrm{O}^{2-}} / a_{\mathrm{CO}_{3}^{2-}}
$$

the metal oxide solubility can also be related to $p_{\mathrm{CO}_{2}}$ and oxide activity

$$
K_{\mathrm{p}}^{\prime}=\left(x_{\mathrm{Pb}^{2+}}\right) /\left[p_{\mathrm{CO}_{2}}{ }^{n} a_{\mathrm{O}^{2-}}{ }^{(n-1)}\right]
$$

At a fixed melt composition $\left(x_{\mathrm{Li}}\right)$, the oxide activity and carbon dioxide partial pressure will be in inverse proportion when the carbonate activity stays constant. To estimate the anion concentration in the melt, the dissociation constant, $K_{\mathrm{d}}$, for the $\mathrm{Li} / \mathrm{K}$ mixed carbonate was taken from Andersen, ${ }^{23}$ who obtained it by means of thermodynamic EMF measurements. For the $\mathrm{Li} / \mathrm{K}=50 / 50$ melt at $650^{\circ} \mathrm{C}$ he gives $\log K_{\mathrm{d}}=-7.51$. This corresponds, at $p_{\mathrm{CO}_{2}}=1 \mathrm{~atm}$, for example, to the activity ratio of oxide ion to carbonate anion of $10^{-8}$.

In the EMF cell, the lead electrode is in equilibrium with the dissolved metal ions, i.e., the complex $\mathrm{Pb}\left(\mathrm{CO}_{3}\right)_{n}^{-2 n+2}$. The cell reactions can therefore be written as

$$
\begin{array}{ccc}
\text { anodic reaction } \mathrm{Pb}+n \mathrm{CO}_{3,(\mathrm{R})}^{2-} \rightleftarrows \mathrm{Pb}\left(\mathrm{CO}_{3}\right)_{n,(\mathrm{R})}^{-2 n+2}+2 \mathrm{e}^{-} \\
\text {cathodic reaction } \mathrm{Pb}\left(\mathrm{CO}_{3}\right)_{n,(\mathrm{M})}^{-2 n+2}+2 \mathrm{e}^{-} \rightleftarrows \mathrm{Pb}+n \mathrm{CO}_{3,(\mathrm{M})}^{2-} \\
\text { overall reaction } \mathrm{Pb}\left(\mathrm{CO}_{3}\right)_{n,(\mathrm{M})}^{-2 n+2}+n \mathrm{CO}_{3,(\mathrm{R})}^{2-} \rightleftarrows \mathrm{Pb}\left(\mathrm{CO}_{3}\right)_{n,(\mathrm{R})}^{-2 n+2} \\
+n \mathrm{CO}_{3,(\mathrm{M})}^{2-}
\end{array}
$$

The EMF of the cell can be expressed as

$$
E=(R T / 2 F) \ln \left[\left(x_{\mathrm{Pb},(\mathrm{R})}^{2+}\right) /\left(x_{\mathrm{Pb}, \underset{(\mathrm{M})}{2+})}\right]\left[a_{\mathrm{CO}_{3(\mathrm{M})}^{2-}} / a_{\mathrm{CO}_{3(\mathrm{R})}^{2-}}\right]^{n}\right.
$$

Here subscripts $\mathrm{R}$ and $\mathrm{M}$ refer the reference and measurement chambers, respectively. As can be seen, when both melts are saturated with lead oxide, the cell EMF is directly related to the oxide solubility, $\left(x_{\mathrm{Pb}^{2+}}\right)$, and the carbonate activity, $a_{\mathrm{CO}_{3}^{2-}}$, the latter with a power of $n$.

By combining the solvent dissociation constant $K_{\mathrm{d}}$, the EMF can also be expressed as

$$
\begin{array}{r}
E=(R T / 2 F) \ln \left[\left(x_{\mathrm{Pb},(\mathrm{R})}^{2+}\right) /\left(x_{\mathrm{Pb},(\mathrm{M})}^{2+}\right)\right]\left[p_{\mathrm{CO}_{2},(\mathrm{M})} / p_{\mathrm{CO}_{2},(\mathrm{R})}\right]^{n} \\
{\left[a_{\mathrm{O}^{2-},(\mathrm{M})} / a_{\mathrm{O}^{2-},(\mathrm{R})}\right]^{n}}
\end{array}
$$

From the measured oxide solubility and EMF values at different $\mathrm{CO}_{2}$ partial pressures and lithium contents $\left(x_{\mathrm{Li}}\right)$, using Eq. 15, the variation of carbonate ion activity or oxide ion activity can be calculated for different $n$ values.

Figure 7 shows the calculated ratio of oxide ion activity $\left[a_{\mathrm{O}^{2-}}, \mathrm{M}\right) /$ $\left.a_{\mathrm{O}^{2-},(\mathrm{R})}\right]$ in a melt of fixed $\mathrm{Li} / \mathrm{K}(=43 / 57)$ composition but different $\mathrm{CO}_{2}$ partial pressures. It should be remarked that the reference side of the EMF cell is with a melt of $\mathrm{Li} / \mathrm{K}=43 / 57$ and $p_{\mathrm{CO}_{2}}=1 \mathrm{~atm}$. The oxide activity ratio of the measuring-side melt to the reference-side melt is unity when $p_{\mathrm{CO}_{2}}$ of the measuring side is also $1 \mathrm{~atm}$. As the $\mathrm{CO}_{2}$ partial pressure decreases, the oxide ion activity in the measuring-side melt increases accordingly. The solubility of $\mathrm{PbO}$ will also decrease, as seen from the plots in Fig. 4 . The difference of the measured EMF value and the term $(R T / \mathrm{n} F) \ln \left[\left(x_{\mathrm{Pb},{ }_{(\mathrm{R})}^{2+}}\right) /\left(x_{\left.\mathrm{Pb},{ }_{(\mathrm{M}}\right)}^{2+}\right)\right]$ will be accounted for by the pressure and activity terms in Eq.15b. By assuming the number $n=1,2$, and 3 , the corresponding oxide activity ratio is obtained as a function of the $\mathrm{CO}_{2}$ partial pressure, as shown in

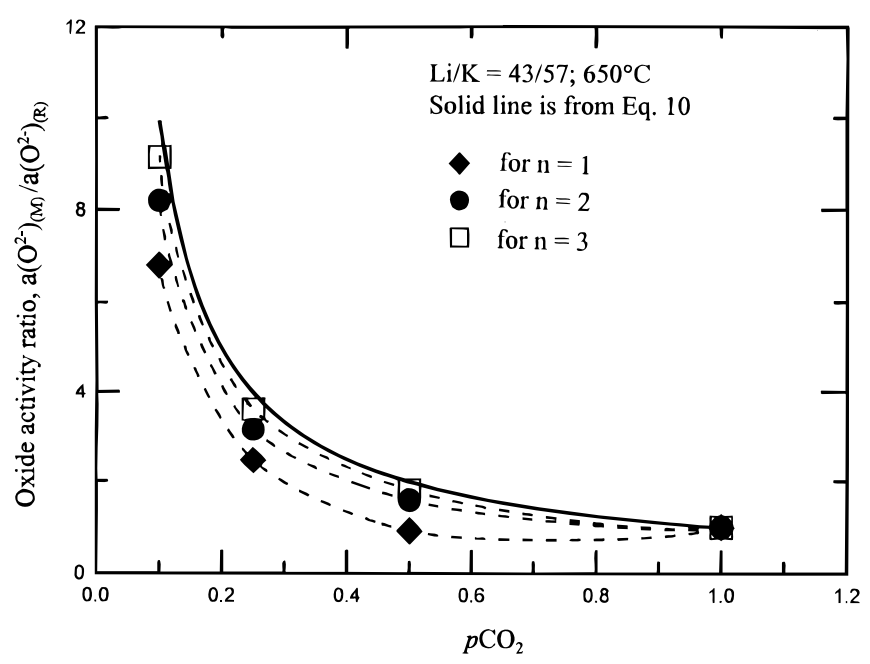

Figure 7. The calculated oxide activity ratios $a_{\mathrm{O}^{2-},(\mathrm{M})} / a_{\mathrm{O}^{2-},(\mathrm{R})}$ as a function of carbon dioxide partial pressure for different coordination number. The reference chamber $(\mathrm{R})$ : $\mathrm{Li} / \mathrm{K}=43 / 57, p_{\mathrm{CO}_{2}}=1 \mathrm{~atm}$; the measuring chamber (M): $\mathrm{Li} / \mathrm{K}=43 / 57$, varying $p_{\mathrm{CO}_{2}}$. Temperature: $650^{\circ} \mathrm{C}$. The solid line is calculated from the solvent equilibrium (Eq. 10). The value of the coordination number used is indicated in the figure.

Fig. 7. The solid line is calculated from the solvent equilibrium $\left[p_{\mathrm{CO}_{2}}\right.$ $a_{\mathrm{O}^{2-}}=$ constant] by taking the carbonate activity as a constant.

It is seen that the oxide activity ratio for $n=1(\diamond)$, which corresponds to the case of no complex formation, does not fit the solvent equilibrium curve. With $n$ increasing from 1 to 3 , the fitting of the calculated points from EMF data to the solvent equilibrium curve is very much improved. This is a strong indication that the dissolution of lead oxide in alkali carbonates may involve a formation of complex ions.

The measurements at $p_{\mathrm{CO}_{2}}=1$ with melts of different lithium contents were further treated as follows. Here it is assumed that the equilibrium constant $\left(K_{\mathrm{p}}\right)$ is only a function of temperature (not varying with the change in lithium content) and the contribution of the liquid junction potential to the measured EMF can be neglected in the range of lithium content studied.

From the solubility data of $\mathrm{PbO}$ in melts with $\mathrm{Li} / \mathrm{K}=43 / 57$, $51 / 49$, and $62 / 38$ at $p_{\mathrm{CO}_{2}}=1 \mathrm{~atm}$, the variation of oxide ion activity ratio $a_{\mathrm{O}^{2-},(\mathrm{M})} / a_{\mathrm{O}^{2-}, \text { (R) }}$ can be calculated as a function of the coordination number, $n$. Thus calculated ratios $(\square)$ are plotted with dashed lines in Fig. 8. On the other hand, the ratio $a_{\mathrm{O}^{2-},(\mathrm{M})} / a_{\left.\mathrm{O}^{2-}, \mathrm{R}\right)}$, also as a function $n$, can be obtained from the EMF data (Eq. 15b) for different $\mathrm{Li} / \mathrm{K}$ compositions in the melt. The obtained ratios $(X)$, as a function of the coordination number, $n$, are plotted with solid lines in Fig. 8.

The comparison of the results gives a value of $n$ (where the two curves cross each other) equal to about 2.5. Considering the above assumptions made for this calculation, especially the constant activity coefficient and the negligible liquid junction potential, a good estimate of the $n$ value between 2 and 3 can be proposed. This will apparently give the complex species $\mathrm{Pb}\left(\mathrm{CO}_{3}\right)_{2}^{-2}$ and $\mathrm{Pb}\left(\mathrm{CO}_{3}\right)_{3}^{-4}$ and the following reactions might be written

$$
\mathrm{PbO}+\mathrm{CO}_{2}+\mathrm{CO}_{3}^{2-} \rightleftarrows\left[\mathrm{Pb}\left(\mathrm{CO}_{3}\right)_{2}\right]^{-2}
$$

and/or

$$
\mathrm{PbO}+\mathrm{CO}_{2}+2 \mathrm{CO}_{3}^{2-} \rightleftarrows\left[\mathrm{Pb}\left(\mathrm{CO}_{3}\right)_{3}\right]^{-4}
$$

Evidence for complexes of transition metal and other metal ions in molten sulfate, chloride, and fluoride melts is well known. ${ }^{24}$ In molten alkali carbonates, there is obviously a competition between the alkali metal and the transition metal ions for carbonate anions. The result of the competition will of course depend on the relative attracting power of the metal ion. Lithium ion with the smallest 


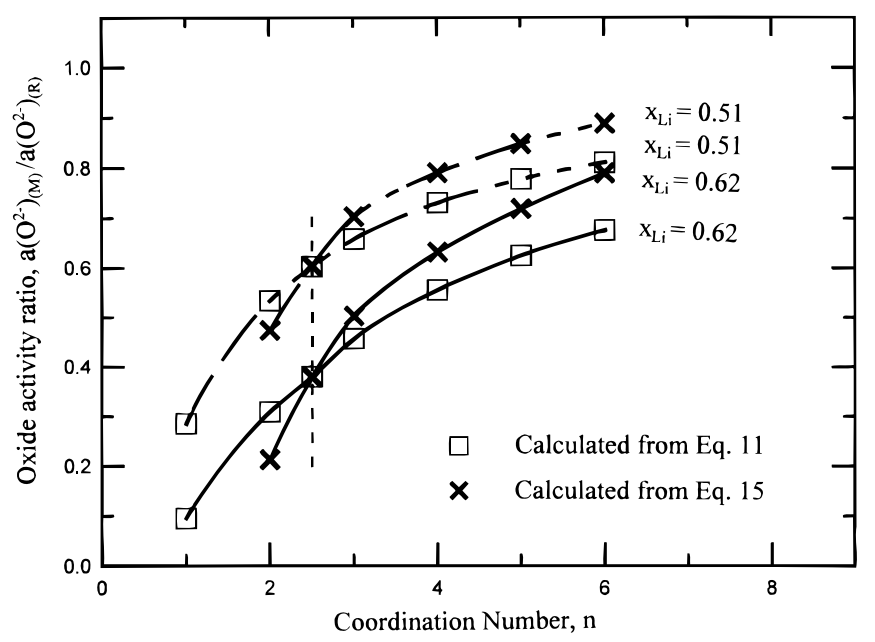

Figure 8. The calculated oxide activity ratios $a_{\mathrm{O}^{2-},(\mathrm{M})} / a_{\mathrm{O}^{2-},(\mathrm{R})}$ as a function of the coordination number. The reference chamber $(\mathrm{R}) \mathrm{Li} / \mathrm{K}=43 / 57, p_{\mathrm{CO}_{2}}$ $=1 \mathrm{~atm}$; the measuring chamber $(\mathrm{M})$ : Varying $\mathrm{Li} / \mathrm{K}$ composition, $p_{\mathrm{CO}_{2}}=1$ atm. Temperature: $650^{\circ} \mathrm{C}$. The solid lines $(\mathrm{X})$ are from the solubility data, and the dashed lines $(\square)$ are from the solubility and EMF measurements. The lithium mole fraction of melts is indicated in the figure.

radius, is of the greatest polarizing power and would render the complex ions unstable. This will help to explain the lithium effect on the solubility of metal oxides.

From the very similar solubility behavior of $\mathrm{NiO}$ and $\mathrm{PbO}$, one might expect a similar complex chemistry for both nickel oxide and lead oxide. As discussed above, the lithium effect on the $\mathrm{NiO}$ solubility can be virtually understood with the help of the assumed complex formation. Moreover, the stability of complex ions is not affected only by the acid/base chemistry of the melt, and therefore the variant slopes of solubility-basicity lines, as found in measurements by Orfield and Shores, ${ }^{3,6}$ are not completely surprising.

Additionally, the temperature coefficient of the $\mathrm{NiO}$ solubility was reported to be negative for the acidic dissolution in a wide range of the melt composition. ${ }^{6,7}$ When plotting the slopes of acid dissolution lines against the temperature difference between the melt temperature and the melting point of the solvent, Orfield and Shores ${ }^{6}$ found that the slope decreases from about 1.5 to about 0.7 as the temperature difference increases up to $100^{\circ} \mathrm{C}$. When the temperature difference exceeds $100^{\circ} \mathrm{C}$ (in the range from 100 to $400^{\circ} \mathrm{C}$ ), the slope becomes constant with a value of about 0.7 , regardless of components or composition of carbonate melts. This behavior is also expected by considering the fact that the thermal stability of the complex ions is generally temperature dependent. The physical structure of the ionic melt and complex ions will probably change as the temperature increases.

During the operation of molten carbonate fuel cells, the dissolution product of the nickel oxide cathode is assumed to migrate toward the negative anode and to be reduced in the vicinity of the anode, resulting in the so-called short-circuiting. ${ }^{15}$ In this connection, a simply positively charged metal ion $\left(\mathrm{Ni}^{2+}\right)$ from the dissolution of a $\mathrm{NiO}$ cathode seems more likely if only electromigration is considered. However in light of the Nernst-Planck flux equation, a migration of a negatively charged ion toward the negative anode can occur when the concentration gradient is large enough. This is well known for electrochemical deposition of negatively charged complex species in, e.g., aluminum and magnesium electrolysis.

\section{Conclusions}

Solubilities of $\mathrm{PbO}, \mathrm{NiO}, \mathrm{Fe}_{2} \mathrm{O}_{3}$, and $\mathrm{Bi}_{2} \mathrm{O}_{3}$ in molten $\mathrm{Li} / \mathrm{K}$ carbonates have been measured at $650^{\circ} \mathrm{C}$ under different pressure of carbon dioxide. As the lithium mole fraction increases from 0.43 to 0.62 in the melt, the solubilities of $\mathrm{NiO}$ and $\mathrm{PbO}$ decrease while those of $\mathrm{Fe}_{2} \mathrm{O}_{3}$, and $\mathrm{Bi}_{2} \mathrm{O}_{3}$ remain approximately constant. At a fixed composition of the melt, $\mathrm{NiO}$ and $\mathrm{PbO}$ dissolve in the carbonates either in an acidic or a basic mode, as the partial pressure of carbon dioxide varies.

Both decreasing $\mathrm{CO}_{2}$ pressure and increasing lithium content result in a reduction in the $\mathrm{PbO}$ solubility in the melt. On the contrary, the EMF measurement shows opposite effects, i.e., decreasing $\mathrm{CO}_{2}$ pressure leads to more negative EMF values but increasing lithium content gives more positive EMF values. This contradiction is explained by the assumption of complex formation upon the dissolution of metal oxides in alkali carbonate melts.

By means of a model of complex formation, the following reactions are suggested for the dissolution of lead oxide in molten carbonates

$$
\mathrm{PbO}+\mathrm{CO}_{2}+\mathrm{CO}_{3}^{2-} \rightleftarrows\left[\mathrm{Pb}\left(\mathrm{CO}_{3}\right)_{2}\right]^{-2}
$$

and/or

$$
\mathrm{PbO}+\mathrm{CO}_{2}+2 \mathrm{CO}_{3}^{2-} \rightleftarrows\left[\mathrm{Pb}\left(\mathrm{CO}_{3}\right)_{3}\right]^{-4}
$$

A similar chemistry for nickel oxide might be expected, which explains the unusual solubility behavior of $\mathrm{NiO}$ in carbonate melts, i.e., the decreased solubility with increasing lithium content.

\section{Acknowledgment}

$\mathrm{K}$. Fehrend is thanked for performing part of the solubility measurements. Thanks are also extended to Dr. B. K. Andersen for valuable discussion.

Technical University of Denmark assisted in meeting the publication costs of this article.

\section{References}

1. M. Schenke and G. H. J. Broers, in Power Sources 1966, D. H. Collins, Editor, p. 459, Pergamon, Oxford (1967).

2. J. Trachtenberg and D. F. Cole, in Fuel Cell Systems-II, Advances in Chemistry Series 90, R. F. Gould, Editor, American Chemical Society, Washington, DC (1969).

3. M. L. Orfield and D. A. Shores, J. Electrochem. Soc., 135, 1662 (1988).

4. C. E. Baumgartner, in Proceedings of the Symposium on Molten Carbonate Fuel Cell Technology, J. R. Selman and T. D. Claar, Editors, Vol. 84-13, p. 417, The Electrochemical Society Proceedings Series, Pennington, NJ (1984).

5. T. D. Kaun, in Proceedings of Fourth International Symposium on Molten Salts, M Blander, D. S. Newman, M.-L. Saboungi, G. Mamantov, and K. Johnson, Editors, PV 84-2, p. 489, The Electrochemical Society Proceedings Series, Pennington, NJ (1984).

6. M. L. Orfield and D. A. Shores, J. Electrochem. Soc., 136, 2862 (1989).

7. K. Ota, S. Mitsushima, S. Kato, S. Asano, H. Yoshitake, and N. Kamiya, J. Electrochem. Soc., 139, 667 (1992).

8. Y. Ito, K. Tsuru, J. Oishi, Y. Miyazaki, and T. Kodama, J. Power Sources, 23, 357 (1988).

9. B. Malinowska, M. Cassir, F. Delcorso, and J. Devynck, J. Electroanal. Chem., 389, 21 (1995).

10. J. D. Doyon, T. Gilbert, G. Davies, and L. Paetsch, J. Electrochem. Soc., 134, 3035 (1987).

11. L. Plomp, J. B. J. Veldhuis, E. F. Sitters, and S. B. van der Molen, J. Power Sources, 39, 369 (1992).

12. C. E. Baumgartner, J. Am. Ceram. Soc., 67, 460 (1984)

13. J. L. Smith, G. H. Kucera, N. Q. Minh, R. D. Pierce, and J. P. Ackerman, Corrosion, 342, 1 (1985).

14. C. E. Baumgartner, R. H. Arendt, C. D. Iacovangelo, and B. R. Karas, J. Electrochem. Soc., 131, 2217 (1984).

15. H. S. Hsu, J. H. DeVan, and M. Howell, J. Electrochem. Soc., 134, 2146 (1987).

16. K. Ota, M. Nakamura, H. Yokokawa, H. Yoshitake, Y. Abe, and N. Kamiya, Denki Kagaku, 62, 165 (1994).

17. L. Plomp, E. F. Siters, C. Vessies, and F. C. Eckers, J. Electrochem. Soc., 138, 629 (1991).

18. J. B. Veldhuis, F. C. Eckes, and L. Plomp, J. Electrochem. Soc., 139, L9 (1992).

19. K. Ota, Y. Takeishi, S. Shibata, H. Yoshitake, N. Kamiya, and N. Yamazaki, J. Electrochem. Soc., 142, 3322 (1995).

20. C. E. Baumgartner, J. Am. Ceram. Soc., 68, 456 (1985).

21. H. Lux, Z. Electrochem., 45, 303 (1939).

22. H. Flood and T. Forland, Acta Chem. Scand., 1, 592, (1947)

23. B. K. Andersen, Ph.D. Thesis, The Technical University of Denmark, Syngby (1975).

24. See, for example, (a) J. H. von Barner, P. B. Brekke, and N. J. Bjerrum, Inorg. Chem., 24, 2162 (1985); (b) J. H. von Barner, E. Christensen, N. J. Bjerrum, and B. Gilbert, Inorg. Chem., 30, 561 (1991). 